\title{
BLENDED LEARNING IN HIGHER MEDICAL EDUCATION: PRINCIPLES AND STRATEGIES OF TEACHING FOREIGN LANGUAGES
}

\author{
Oksana Isayeva (Corresponding author), Myroslava Shumylo, Irena Khmilyar, Iryna Myskiv \\ Lviv Polytechnic National University, Lviv, Ukraine \\ oksana.lviv567@gmail.com \\ Oksana Mylyk \\ Danylo Halytsky Lviv National Medical University, Lviv, Ukraine
}

\begin{abstract}
The article highlights the new approach to teaching a foreign language to medical students as a reasonable mixed method of traditional teaching and the use of modern technologies. Teaching process at higher medical educational institutions is based on innovative didactic technologies, mechanisms and procedures. Many theories suggest implementation of combined classroom and online teaching called blended or hybrid learning. The aim of this investigation is to develop practical recommendations for successful integration of blended learning with traditional teaching medical students at the Danylo Halytsky Lviv National Medical University. Web-based technology stimulates and promotes self-learning, keeps the learner at the centre of the learning process using personality-oriented and technology-mediated approaches. E-learning promotes autonomy and motivates students to learn throughout the life performing specific tasks before or after classroom learning. The research involved 47 groups of students studying General Medicine at Danylo Halytsky Lviv National Medical University (602 second-year students, 2017-2018 academic year). The experiment consisted of $40 \%$ of e-learning and $60 \%$ of classroom teaching. Assessing performance, we concluded that students' academic performance results improved from $15 \%$ to $23 \%$ depending on the language skill due to the integration of blended learning strategies into the teaching process. Blended learning also assists students to choose and interpret required tasks, to assess cases related to future medical profession, and to apply compulsory information, which requires proficiency and practical skills.
\end{abstract}

Keywords: blended learning; e-learning; traditional teaching, medical student; humanities, English language.

\section{Introduction}

Teaching process at higher medical educational institutions is based on innovative didactic technologies, mechanisms and procedures approved by the Ministry of Education and Science and the Ministry of Health of Ukraine, corresponding to the principles of medical education of the European Higher Education Area. Currently, the situation with higher medical institutions requires implementation of innovations in the process of teaching foreign languages. The Cabinet of Ministers of Ukraine approved the Strategy for the Development of Medical Education in Ukraine by the Order No 95-p dated February 27, 2019, which is planned for 10 years. The implementation of the Strategy provides the creation of a high-quality system of medical education with a high level of specialists' training, which aims to improve the quality of higher medical education; to transform qualitatively postgraduate education; to create effective funding and management; to rethink the academic culture; to stimulate the development of scientific research; to advance the level of English.

Thus, researchers are in the process of seeking relevant efficient methods for teaching foreign languages as medical students have a variety of perspectives and prime necessity in learning languages. To optimise the process of learning humanities means to improve the quality of learning culture and values of professional communication in present medical students and to promote personal motivation of future doctors at the English classes (Isayeva, 2013).

Therefore, it is expedient to use e-learning as a mode which helps teach innovatively according to modern requirements and to improve teaching process and students' practical skills. This variation of teaching is also known as a flipped classroom, which is being implemented in the basic sciences. In such form of education, medical students get ready for the class by fulfilling tasks out of classes, frequently in the form of a video lecture. Then, they come to the classroom to practice and solve problems, participate in teamwork.

The goals of the article are to study the efficiency of blended learning for language learning and to share our practical experience on successful integration of blended learning with traditional teaching medical students at Danylo Halytsky Lviv National Medical University in Ukraine.

Isayeva, O., Shumylo, M., Khmilyar, I., Myskiv, I., \& Mylyk, O. (2020). Blended learning in higher medical education: principles and strategies of teaching foreign languages. Advanced education, 14, 11-18. https://doi.org/10.20535/2410-8286.183725 


\section{Literature review}

Flipped classes (FC) have been used in medical education since 1990s and have gained wide recognition as an efficient tool to facilitate an engaging learning process. The essence of such classes is to assign didactic materials to students for self-paced learning in order to use class time more productive involving such interactive activities as discussions, problem solving, reflections etc. The time spent with students face to face provides more opportunities for teachers not only develop hard skills but soft skills as well such as team work, creativity, communication, self-initiated learning skills, cognitive skills etc. (Millard, 2012).

The term "blended learning" was first introduced in business relating to corporate training (Sharma and Barrett, 2007). Then it was implemented into the process of higher education (MacDonald, 2006; Mohammed Mansur Ibrahim, Muesser Nat, 2019; Napier, Dekhane, and Smith, 2011; Porter and Graham, 2015; Alebaikan and Troudi, 2010) and finally, this term is closely connected with foreign language teaching and learning. Based on scientists' investigations, the term itself has not been fully adopted, but it can be referred to as "hybrid or mixed learning" (Stracke, 2007; Shea, Joaquin, and Gorzycki, 2015; Rahardjanto, Husamah, and Fauzi, 2019); "e-learning" or "b-learning" (Banados, 2006; Boelens, De Wever, and Voet, 2017; Kenney and Newcombe, 2011; Norberg, Dziuban, and Moskal, 2011; Peterson, Horn, 2016; Wang, Han, Yang, 2015). The scientists (Smith and Kurthen, 2007; Gruba and Hinkelman, 2012) made an attempt to differentiate these terms by using percentages (Table 1 ).

Table 1. Categorisation of terms related to blended learning

\begin{tabular}{|c|l|}
\hline Term & \multicolumn{1}{|c|}{ Definition } \\
\hline web-enhanced & $\begin{array}{l}\text { subjects that make use of a minimal amount of online materials, such as posting a } \\
\text { syllabus and course announcements }\end{array}$ \\
\hline blended & $\begin{array}{l}\text { subjects that utilise some significant online activities in otherwise face-to-face } \\
\text { learning, but less than 45 per cent }\end{array}$ \\
\hline hybrid & $\begin{array}{l}\text { subjects in which online activities replace 45-80 per cent } \\
\text { of face-to-face class meetings }\end{array}$ \\
\hline fully online & subjects in which 80 per cent or more of learning materials are conducted online \\
\hline
\end{tabular}

However, this strategy requires specific conditions and schemes of implementation. Thus, Han, Resch and Kovach (2013) suggested the scheme of flipped classroom integration: 1) plan learning activities, 2) create opportunities for pre-learning of didactic materials, 3) develop diagnostic tools for assessments of learning gaps, 4) integrate active learning strategies and technology into the learning process. In order to implement FC successfully, educators Hurtubise et al. (2015) developed recommendations to follow up:

....consider your learners and how they learn; make learning goals explicit; consider the learners' cognitive load including all their assessments and assignments; accurately estimate and communicate the amount of time you expect students will spend on didactic material outside of class; provide an online schedule and make learning materials easy to find and easy to use; ensure assessment methods are competency-based and match your goals (p. 39).

Both suggestions highlight the most critical factor is students' learning gaps and background assessment. Unfortunately, in our realm teachers neglect this stage.

The implementation of FC implies the application of various educational technologies in and out of classes. For example, Hew and Lo ( 2018) suggest using online quizzes to revise the previously learnt material and their empirical research evidenced statistically significant improvement in academic achievement of students involved into FC. The findings of Lewis's (2019) research are in a line with Hew and Lo's (2018) results and prove the positive effect of FC for future doctors. Moreover, the researcher claims that FC stimulates student-centred, autonomous, active learning.

Concerning the integration of FC into the English classes, according to Basal (2015) FC provides the authenticity of learning materials that is crucial for language learners. Santikarn and Wichadee (2018) claim that FC improves speaking skills of students due to the increased time for interaction during in-class activities. They also indicate the rise of motivation of students to learn a language as they enjoy the way they acquire knowledge at any place and at their own pace. The results of the empirical research carried out by Bouchefra (2017) demonstrate that writing skills can also be improved by FC.

The researchers (Sharma and Barrett, 2007) also consider that cost, convenience and ability to work in a particular time and at own pace, the reasons they cite for blended learning being employed in the business world, are also applicable to language teaching. Combination of e-learning and digital technologies in making both teaching and learning processes more flexible and dynamic also promotes medical students to 
obtain sufficient language practice according to their interests, skills and the level of development. Simultaneously, students can work individually, fulfilling the task unlimited times or at any time, totally or in parts using cooperative learning with group mates or autonomous learning. Currently, a lot of students prefer to learn independently and consistently without a teacher.

Thus, we hope that face-to-face teaching might develop students' fluency through in-class discussion, improve students' cognition and motivate the student to work in a group to achieve the objectives while blended learning component might improve students' creativity. Face-to-face learning determines students at the centre of their own learning experience and motivates them to work with others to complete a common task. Students use technology to do specific tasks before and during face-to-face classes or to prepare for 'integrated' approach. The researchers (Thorne, 2003; Cheung, Wang, Au, and Xie, 2018; Stockwell, Stockwell, Cennamo, and Jiang, 2015; Tsabala, Ndeya-Ndereya, and van der Merwe, 2014; Castro, 2019; Westerlaken, 2019) state that blended learning could be one of the most important educational advances in the century. It means the identical significance of both methods".

Nevertheless, we agree with the statement that "blended learning" makes emphasis on enabling medical students to accumulate knowledge through discourse, discussion, sharing of perspectives and sources, analysis of resources from multiple sources, and teacher's feedback. Social media encourage the development of socio-cultural skills, where students may share experiences, discuss principles and challenges, and learn from each other (Sharma and Barrett, 2007; Naaj, Nachouki, and Ankit, 2012; Ellis, Pardo, and Han, 2016; Pardede, 2013; So and Brush, 2008). The significance of foreign language teaching is to make medical students more comprehensively developed personalities; make them understand the experiences of medicine, health, illness, sickness and disability from different viewpoints, i.e. patients, physicians or family members. The value of this experience is to encourage reflection, to promote selfawareness, assertiveness and responsibility and to stimulate discussion on difficult issues: e.g. death and dying, suffering and pain, health and sickness etc.

Having analysed the numerous research on the topic, we have come to the conclusion that a flipped classroom can be considered as the next frontier of medical education, particularly foreign language teaching.

\section{Research methods}

\section{Data collection tools and procedure}

We have chosen the mixed approach for our research methodology as we used quantitative (pre- and posttest on academic achievements) and qualitative (questionnaire) data collection tools for students and teachers after the experience of FC implementation. Tests were developed based on the material suggested for out of class and in class learning including the assessment of four language skills: speaking, writing, listening and reading. The procedure of the research was the following: we provided a course of ESP that included $40 \%$ of FC and $60 \%$ of face-to-face classroom teaching with the integration of technologies and video learning materials. Students' literacy and language skills level was assessed before and after the course. Teachers and students' perception of this innovation was evaluated by a questionnaire developed for teachers and students. Students' questionnaire included three questions:

1. What changes have you noticed in the process of a language teaching?

2. What did you like and dislike among the introduced innovations?

3. What would you like to change in the process of language learning at the university?

Teachers' questionnaire included four questions:

1. What challenges did you encounter while FC implementation?

2. What language skills were mostly improved?

3. How did you combine traditional methods with FC strategies?

4. Give your own ideas for further improvement of teaching process

\section{Participants}

The investigation involved 47 groups of students studying general medicine at Danylo Halytsky Lviv National Medical University and ESP at the Department of Latin and Foreign Languages (602 second-year students, 2017-2018 academic year) from Master of medicine programme (qualification "Doctor", speciality 222 Medicine, knowledge branch 22 Health care). Provision of the quality of higher education at Danylo Halytsky Lviv National Medical University is accomplished according to the "Strategy, policy, and procedures of provision of education quality at Danylo Halytsky Lviv National Medical University", elaborated based on requirements of the Law of Ukraine "On higher education dated 01.07.2014 №1556-VII. Students had one class of ESP per week for 1.5 years. The students were informed about the experiment and 
gave their agreement for the participation and academic achievement processing. Students could refuse to participate at any stage of the experiment without any academic consequences. The procedure of the research was approved by the external experts from Lviv Polytechnic National University, Department of Foreign Languages (Professor N. Mukan, Associate Professor O. Bilyk, Associate Professor J. Zakaulova). The experts ensured that the investigation was performed in proper conditions and confirmed the reliability of the obtained results.

\section{Results}

Assessing students' academic performance, we concluded that students' quantitative results before and after the experiment increased (Table2). The test included four parts for each language skill 25 grades maximum per part, total 100 points for the test. We calculated the statistical data in percentages how many students coped with the parts of the test with grades more than 20 according to the grading scale 100 points as a total excellent grade.

Table 2. Academic performance results

\begin{tabular}{|c|c|c|}
\hline Competence & Initial findings & Final findings \\
\hline Reading & $84 \%$ & $89 \%$ \\
\hline Listening & $75 \%$ & $86 \%$ \\
\hline Speaking & $64 \%$ & $82 \%$ \\
\hline Writing & $57 \%$ & $79 \%$ \\
\hline
\end{tabular}

Regarding qualitative findings we found out that at the beginning of studying most students and teachers preferred traditional teaching methods. Figure 1 demonstrates the distribution of methods before the experiment.

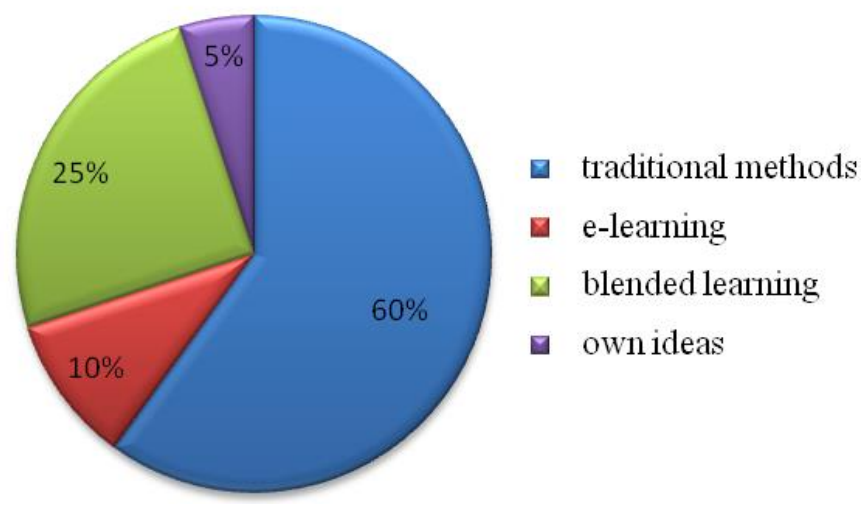

Fig. 1. Distribution of teaching methods before the experiment

Figure 2 depicts the difference in perception of FC after the experiment.

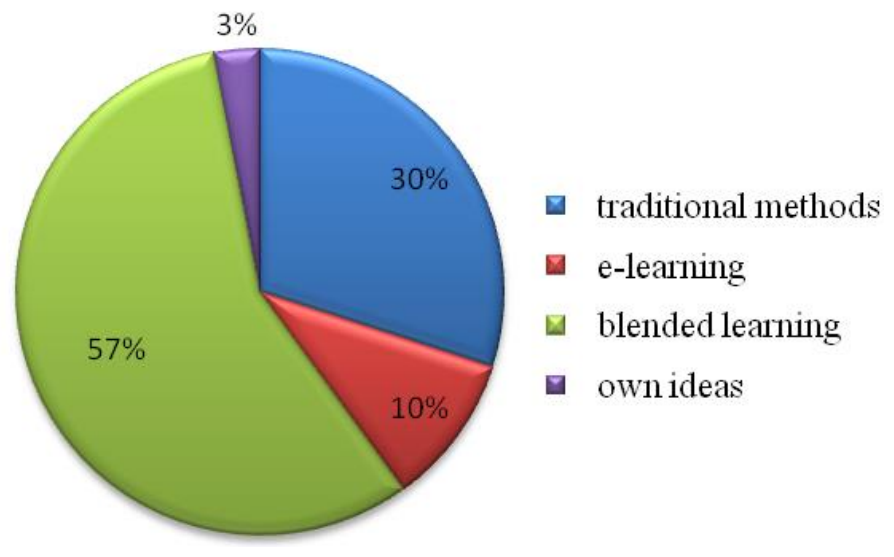

Fig.2. Distribution of teaching methods after the experiment 
Overall, it is clear that at the beginning of studying students and teachers considered traditional methods the most reasonable ones (60\%) while blended learning comprised $25 \%$. At the end of studying after using a blended method of teaching, the viewpoint dramatically changed. The proportion of blended methods of learning rose significantly and nearly doubled (57\%). In contrast, there was a remarkable drop in traditional methods and it decreased to $30 \%$. A very slight decrease of $2 \%$ was in the proportion accounted for students' own ideas for further improvement of teaching process. The number of students preferring elearning remained stable. Survey participants, who are last term medical students, are $75 \%$ more likely to think about information technologies in medical education as the most significant part of learning foreign languages, while only $25 \%$ of current first-year medical students support this idea.

\section{Discussion}

We consider it quite possible to introduce blended mode of learning at higher medical educational institutions that enables a student to master certain material himself/herself at a time convenient for him/her and at his/her own pace. However, at the same time, it does not deprive him/her of the opportunity to communicate in a foreign language in a classroom. A number of creative projects included in each module motivate students to independent and creative work. These are materials accommodated to functionally illiterate adults intended for helping them solve the problems of their everyday life through the development of basic skills and encouraging to reading for information about the world and the development of abstract thinking (Mukan, 2016). Moreover, they have the possibility to exchange experience on projects, discuss and evaluate the activities of other students. Our research finding are in a line with Peterson's (2016) research. $\mathrm{He}$ is Professor and Director of the Program on Education Policy and Governance at the Harvard Kennedy School, who underlined that "a student can learn effectively via computer if an educator is around to assist and supplement, and teachers are realising the power of computers - properly used - have to enhance their craft" (Peterson and Horn, 2016).

Corresponding to current theories, we distinguish two key forms of teaching which can be united with blended learning synchronous and asynchronous teaching. Synchronous (or traditional) teaching proceeds in an actual time, in which students obtain accessible theoretical knowledge and practical experience simultaneously with immediate response in real conditions. Asynchronous (or combined) teaching is usually implied at any convenient time for students and they can choose online instructions for getting required abilities and experience, but they cannot reply in real conditions.

Blended learning enables to use many different forms and methods in foreign language teaching. Internet resources (blogs, sites, portals etc.) should be updated from the foreign websites and studying course must be created based on Digital media, YouTube videos, InnerBody.com or TED talks and open educational resources in the form of short presentations, reports, simulations, round tables and other performances which enable both teachers and students to obtain and apply knowledge and gain practical skills. The BioDigital Human is a virtual 3D body that visualises human anatomy, disease and treatments in an interactive 3D web platform; www.webmd.com/digestive-disorders/picture-of-the-abdomen gives the description of the abdomen, its localisation and main organs, digestive disorders and abdomen conditions, tests and treatment; https://www.free-anatomy-quiz.com contains more than 200 free multiple-choice quizzes to help students learn the anatomy, physiology and pathology of the human body that are excellent educational resources for future doctors which can be downloaded free as educational sources. They are very convenient for students' mastering self-study skills and allow viewing a video collection of prominent specialists in numerous fields of medicine or checking personal knowledge through testing. Students may also have the opportunity to become familiar with Computer-based Testing of the USMLE sample items. Students' test scores will be increased.

Our traditional educational course is organised based on available scientific and pedagogical conditions, considering the opportunities of current information technologies. It focuses on the training of creative, sophisticated, harmoniously developed future doctors capable of constant development of scientific knowledge, academic and professional mobility. Syllabi are directed at rapid adaptation to changes and development in the social and cultural domain as well as in the field of medicine. A 2014 survey conducted by the Ohio State University College of Medicine identified the most important aspects of medical school training as (1) clinical problem solving, (2) learning how to acquire knowledge, (3) developing bedside manner, (4) teamwork, (5) technology training, and (6) clinical research. Thus, training doctors requires deviation from traditional teaching methods (Ohio State University, n.d.).

Consequently, we consider that modern methods in combination with traditional ones help teachers achieve better results and obtain a high-quality education. New goals and ways of their implementation appear in higher medical education due to modernisation of the system of higher professional training as well 
as implementation of innovative teaching methods and technologies. Previously, we used the web-enhanced method in teaching foreign languages at the medical university. It involved finding additional information based on the practical lesson material.

However, four years ago we started foreign language training at Lviv Danylo Halytsky national medical university using a blended method of training, which implies $40 \%$ of e-learning applying various activities. Formation of the socio-cultural component in teaching professional English communication is a phased process of mastering professional and communicative skills, first learnt and then accurately combined with certain verbal actions of professional and cultural character. This component is the main principle in the development of contemporary educational processes, namely competence approach and cultural communicative competence (Isayeva, 2013).

According to own practical experience, online training should be used as a supplementary course to face-to-face teaching at higher medical educational establishments. The main reason is that practical hours are limited but not abolished for the course of foreign languages at medical universities in Ukraine. Accordingly, hours for self-study are constantly being increased and e-learning should be used in the teaching process. It serves as a means for self-study and doing homework, for preparing practical lessons more effectively as well as for simplifying and improving the quality of students' training for qualification licensing examination "Krok" and USMLE tests in English, which have to be passed in order to be eligible to work in their profession. E-training contributes to the formation of modern skills as culture, intellectual work, and experience with the latest means of communication, and prepares medical students for subsequent adaptation to the numerous situations of professional interaction and independent cognitive activity. Thus, future doctors should be taught from the position of mutual understanding and collaboration rather than trying to impose traditional medical practices that are unlikely to be effective.

Nevertheless, e-learning methods are sometimes complicated for both students and teachers, because foreign language teaching is hardly comprehensible without classroom learning considering the opportunity of oral communication with a teacher. The scientist (Sharma, 2007) proposes, "for blended learning to be effective, the two-component parts should be integrated with the technology complementing and not replacing the efforts of the teacher" and we support this statement. The teacher may also heed to the size of the task, which has to be prepared carefully in advance, the aim and instructions of the task have to be strictly elucidated to the learners using definitions or synonyms. Each task must interest and motivate the students or focus on relevant curriculum content related to current events or concerns. Tasks should be chosen due to students' needs, interests, future profession and practical experience. Students' daily training must foster communication skills based on students' prior knowledge and subject integration leading to innovative information in the field of medicine. Students tend to have more motivation to learn when they realise that classroom exercises represent their future practice.

However, productive skills are defined in speaking and writing. In each case, foreign language teaching involves speaking and original listening. It means that sounds, stress system and intonation patterns should be taught in team or group work where students can make up dialogues, discussions based on real professional or ethical issues. Students must be ready for discussions in order to boost critical thinking and creativity. Writing involves spelling, grammar system, vocabulary and punctuation. Finally, writing skills, especially, mechanical and grammatical aspects with vocabulary lists should be emphasised. The students also have to learn peculiarities of linking sentences both in speech and in writing. We define these types of skills to be very significant for future doctors, as they must achieve fluency in speaking due to productive listening and accurate writing. Both oral and writing skills may be successfully improved via combined elearning and face-to-face teaching.

Thus, blended learning can help improve students' communication competence: they can effectively communicate with other members of the health care team, patients and their relatives. Modern communication technologies of the educational process are primarily directed at language knowledge and the ability to apply the knowledge, to interpret or to produce thoughts based on quick assessments and suitable for future medical practice. Communication skills with regular feedback on the acquired behaviour must be combined with personal and professional culture considering future doctors' peculiarities as to improve the patient's health and medical care. Nevertheless, educational programmes of humanities must also focus on the enhancement of interpersonal and communicative skills, which are essential to transform doctor-patient relationships and to optimise patients' health and treatment.

E-learning helps demonstrate the ability to use methods effectively in a specified context in order to engage and motivate students, to develop language skills used in medical practice, students' critical thinking as it helps students to develop a solid foundation in medical terminology, to broaden their skills and personal 
cognitive development. E-learning promotes autonomy and motivates students to learn throughout the life performing specific tasks before or after classroom learning.

Using digital resources, students must be aware in typing, searching necessary information, finding web-based material, being in social media. Substantial improvement of students' language skills and the achievement of desired learning outcomes have been observed due to combined e-learning and face-to-face teaching. Medical students gain new skills due to e-learning or adapt previously face-to-face learned skills for new applications with less effort. Both students and teachers have been satisfied.

\section{Conclusions}

The use of modern information technologies in the training of future doctors allows activating students' work, interacting more effectively with learners and conducting e-learning not only in the process of teaching foreign languages but also in other activities, for example, fostering practical skills to medical students who conduct research work. The advantages of e-learning technologies include flexibility, continuity and systematisation, increasing students' motivation and self-organisation. Innovations lead to more effective students' education as it will enhance patients' care in the future.

Nevertheless, there are drawbacks in online teaching when digital resources are unavailable or do not work properly, sometimes improper connection. There are groups with mixed ability students and many students may not have digits or even may not be the users of internet with e-mails. It is important to mention that e-learning cannot be the only variation of medical education. It can be relevant to teaching humanities and pre-clinical subjects. However, human interaction and clinical experience are important in medical practice. A flipped classroom can only enable students to prepare better for the clinical experience so that they can achieve advancement in their training.

Blended learning turns out to be "a sweet spot" between traditional classroom training and distance learning. It provides the ability to both students and teachers to correctly distribute training hours and use them with maximum efficiency. This form of training makes the knowledge assessment system more objective and less dependent on the teacher, motivates students to search independently the solutions to their tasks using Internet resources, helps to increase their social and professional mobility, social activity, personal enrichment and level of self-awareness.

\section{References:}

Alebaikan, R., \& Troudi, S. (2010). Blended learning in Saudi universities: challenges and perspectives: RLT, 18(1),49-59. https://doi.org/10.1080/09687761003657614

Banados, E. (2006). A blended-learning pedagogical model for teaching and learning EFL successfully through an online interactive multimedia environment. CALICO Journal, 23(3), 533-550. https://doi.org/10.1558/cj.v23i3.533-550

Başal, A. (2015). The Implementation of A Flipped Classroom in Foreign Language Teaching. Turkish Online Journal of Distance Education 16(4). DOI:10.17718/tojde.72185

Boelens, R., De Wever, B., \& Voet, M. (2017). Four key challenges to the design of blended learning: A systematic literature review. Educational Research Review, 22, 1-18. https://doi.org/10.1016/j.edurev.2017.06.001

Boelens, R., Voet, M., \& De Wever, B. (2018). The design of blended learning in response to student diversity in higher education: Instructors' views and use of differentiated instruction in blended learning. Computers \& Education, 120, 197-212. https://doi.org/10.1016/j.compedu.2018.02.009

Bouchefra, M. (2017). The Use of the Flipped Classroom in EFL Writing Classroom. TRANS Internet- journal for cultural studies, 22. Retrieved 26 September from: http://www.inst.at/trans/22/the-use-of-the-flipped-classroom-in-efl-writing-classroom/

Castro, R. (2019). Blended learning in higher education: Trends and capabilities. Education and Information Technologies, 24(4), 2523-2546. https://doi.org/10.1007/s10639-019-09886-3

Cheung, S. K. S., Wang, F. L., Au, O., \& Xie, Y. (2018). Guest editorial: Innovative practices of blended learning. Open Learning: the Journal of Open, Distance and e Learning, 33(2), 80-82. https://doi.org/10.1080/02680513.2018.1455579

Ellis R. A., Pardo, A. Han, F. (2016). Quality in blended learning environments - Significant differences in how students approach learning collaborations. Computers \& Education, 102, 90-102. https://doi.org/10.1016/j.compedu.2016.07.006

Gruba, P., \& Hinkelman, J. (2012). Blended Technologies in Second Language Classrooms. Basingstoke: Palgrave Macmillan. https://doi.org/10.1111/j.1467-8535.2012.01347_6.x

Han, H., Resch, D., Kovach, R. (2013). Educational technology in medical education. Teach Learn Medicine, 25, 539-543. https://doi.org/10.1080/10401334.2013.842914

Hew, K. F., \& Lo, C. K. (2018). Flipped classroom improves student learning in health professions education: a meta-analysis. $B M C$ Med Educ., 18(38). https://doi.org/10.1186/s12909-018-1144-z.

Hurtubise, L., Hall, E., Sheridan, L., Han, H. (2015) The flipped classroom in Medical education: engaging students to build competency. Journal of Medical Education and Curricular Development, 2, 35-43. https://doi.org/10.4137/JMecd.S23895

Husamah, H. (2015). Blended project based learning: Metacognitive awareness of biology education new students. Journal of Education and Learning, 9(4), 274-281. https://doi.org/10.11591/edulearn.v9.i4.2121

Ibrahim, M.M., \& Nat, M. (2019). Blended learning motivation model for instructors in higher education institutions. International Journal of Educational Technology in Higher Education, 16(12). https://doi.org/10.1186/s41239-019-0145-2

Isayeva, O. (2013). Ethics of Future Doctors in the Process of Teaching Foreign Language. American Journal of Educational Research, 1(11), 517-522. https://doi.org/10.12691/education-1-11-10

Kenney, J., Newcombe, E. (2011). Adopting a blended learning approach: challenges encountered and lessons learned in an action 
research study. JALN, 15, 45-57. https://doi.org/10.24059/olj.v15i1.182

Lewis, C.E. (2019). Is the Flipped Classroom a Panacea for Medical Education? Curr Surg Rep, 7(9). https://doi.org/10.1007/s40137-019-0230-4

MacDonald, J. (2006). Blended Learning and Online Tutoring: a good practice guide. Aldershot, Hants, England; Burlington, VT: Gower.

Millard, E. (2012). 5 reasons flipped classrooms work: Turning lectures into homework to boost student engagement and increase technology-fueled creativity. University Business, 12, 26-29. Retrieved 27 September from http://www.universitybusiness.com/article/5-reasons-flipped-classrooms-work

Mukan, N., Fuchyla, O. (2016). Functional literacy learning in the system of adult education in Belgium. Advanced education, 6, 3439. https://doi.org/10.20535/2410-8286.76533

Naaj, M. A., Nachouki, M., \& Ankit, A. (2012). Evaluating student satisfaction with blended learning in a gender-segregated environment. Journal of Information Technology Education: Research, 11(1), 185-200. https://doi.org/10.28945/1692

Napier, N. P., Dekhane, S., \& Smith, S. (2011). Transitioning to blended learning: Understanding student and faculty perceptions. Journal of Asynchronous Learning Networks, 15(1), 20-32. Retrieved 3 November from https://pdfs.semanticscholar.org/f2b7/15fe7c061295246776d3482350fe22f5c118.pdf

Norberg, A., Dziuban, C. D., Moskal, P. D. (2011). A time on based blended learning model. On the Horizon, 19(3), $207-216$. https://doi.org/10.1108/10748121111163913

Pardede, P. (2013). Enhancing Students' Learning Through Blended Learning. Presented at “Seminar Dies Natalis UKI ke-60” held on October 12, 2013 at Kampus UKI Cawang, Jakarta

Peterson, Paul E. \& Horn, Michael B. (2016). The Ideal Blended-Learning Combination. Education Next, 16 (2), 94-95. Retrieved 27 October from https://www.educationnext.org

Porter, W. W., Graham, C. R. (2015). Institutional drivers and barriers to faculty adoption of blended learning in higher education. British Journal of Educational Technology. https://doi.org/10.1111/bjet.12269

Porter, W. W., Graham, C. R., Spring, K. A., \& Welch, K. R. (2014). Blended learning in higher education: Institutional adoption and implementation. Computers \& Education, 75, 185-195. http://doi.org/10.1016/j.compedu.2014.02.011

Rahardjanto, A., Husamah, Fauzi, A. (2019). Hybrid-PjBL: Learning Outcomes, Creative Thinking Skills, and Learning Motivation of Preservice Teacher. International Journal of Instruction, 12(2), 179-192. https://doi.org/10.29333/iji.2019.12212a

Santikarn, B., Wichadee, S. (2018) Flipping the Classroom for English Language Learners: A Study of Learning Performance and Perceptions. iJET, 13 (9). https://doi.org/10.3991/ijet.v13i09.7792

Sharma, P., Barrett, B. (2007). Blended Learning: Using technology in and beyond the language classroom. Oxford: Macmillan.

Shea, J., Joaquin, M. E., Gorzycki, M. (2015). Hybrid course design: Promoting student engagement and success. Journal of Public Affairs Education, 21(4), 539-556. https://doi.org/10.1080/15236803.2015.12002219

Smith, G. G., \& Kurthen, H. (2007). Front-stage and back-stage in hybrid e-learning face-to-face courses. International Jl. on ELearning, 6, 455-474. Retrieved 15 October 2019 from https://www.learntechlib.org/primary/p/20008/

So, H., Brush, T.A. (2008). Student perceptions of collaborative leaning, social presence and satisfaction in a blended learning environment: relationships and critical factors. Comput Educ., 51, 318-336. https://doi.org/10.1016/j.compedu.2007.05.009

Stockwell, B.R., Stockwell, M.S., Cennamo, M., Jiang, E. (2015). Blended learning improves science education. Cell, 162, $993-936$. https://doi.org/10.1016/j.cell.2015.08.009

Stracke, E. (2007). A road to understanding: A qualitative study into why learners drop out of a blended language learning (BLL) environment. ReCALL 19(1), 57-78. https://doi.org/10.1017/S0958344007000511

The Ohio State University College of Medicine (n.d.). College of Medicine News: The State of Medical Education. Retrieved September 29 from http://medicine.osu.edu/news/archive/2014/11/20/the-state-of-medical-education.aspx

Thorne, K. (2003). Learning: How to Integrate Online and Traditional Learning. London Blended: Kogan Page. Kaye Thorne.

Tshabalala, M., Ndeya-Ndereya, C., van der Merwe, T. (2014). Implementing blended learning at a developing university: Obstacles in the way. The Electronic Journal of e-Learning, 12(1), 101-110. Retrieved 3 October 2019 from https://www.learntechlib.org/p/153387/

Wang, Y., Han, X., \& Yang, J. (2015). Revisiting the Blended Learning Literature: Using a Complex Adaptive Systems Framework. Educational Technology \& Society, 18 (2), 380-393. Retrieved 3 October 2019 from https://www.jstor.org/stable/jeductechsoci.18.2.380

Westerlaken, M., Christiaans-Dingelhoff, I., Filius, R. M., de Vries, B., de Bruijne, M. \& van Dam, M. (2019). Blended learning for postgraduates, An interactive experience BMC Medical Education, 19 (289). https://doi.org/10.1186/s12909-019-1717-5

Received: November 11, 2019 Accepted: March 01, 2020 